field of instrument technology and instrumentation. Its editorial policy is stated as serving and unifying the interests of instrument makers, users and technologists. The journal is primarily concerned with commercial rather than laboratory instruments, and it also aims at the publicizing of British instruments abroad. It will, therefore, be acknowledged that the new journal has set itself an impressive and ambitious task. A considerable section of the first issue is given to an account of a recent conference in the United States, with commentaries on the papers so brief as to be of little value in many cases. Another section is devoted to reprints of papers read before the Society of Instrument Technology. It is here that the new journal may serve a most useful purpose, as the papers of the Society have not yet been regularly published in any one journal. Permanent features cover new patents, news of the industry, trade and technical publications, particulars of new companies and a diary of forthcoming events.

\section{Claims for War-time Awards for Inventions}

THE rules of procedure of the Royal Commission on Awards to Inventors were published in September 1946 (Nature, September 28, p. 443). About fifty claims arising from the use of inventions by the British and Allied Governments during the War have so far been referred to the Commission. They relate to a wide field of invention and include claims in respect of 'Mulberry', the flail tank, which was first used in North Africa for destroying enemy mines, plastic armour for use on ships, amphibious tanks, the Bailey bridge, the sticky bomb, and many others. Many of these cases raise complicated scientific and legal issues, and the preparation of a case for hearing takes a considerable time. It has, therefore, been necessary to postpone the first public hearing of the Commission; but it is hoped that a case will be ready in the middle of February or the beginning of March. A committee consisting of the chairman, Lord Justice Cohen, the deputy chairman, Mr. Kenneth Swan, and the secretary has been set up to deal with preliminary matters which may arise in a claim before it is ready for hearing before the full Commission.

\section{Blood Group Reference Laboratory}

SINCE the Galton Laboratory Serum Unit (Medical Research Council), formerly at Cambridge, closed in May last, Dr. R. R. Race, the former director, has moved to the Lister Institute, London, where he is in charge of the new Blood Group Research Unit of the Medical Research Council. Dr. A. E. Mourant, who formerly assisted Dr. Race, has become director of the new Blood Group Reference Laboratory of the Ministry of Health. This Laboratory, which is part of the Ministry of Health Blood Transfusion Service, is also at the Lister Institute, and will provide grouping serum and investigate clinical blood-group problems. The juxtaposition of these two laboratories will be of great mutual benefit and ensure the close association of the theoretical and practical sides of this subject. Hospitals and medical men requiring grouping serum should, in the first instance, apply to their local regional transfusion centre, through which grouping serum will be issued.

\section{Astrology in the Hellenistic Age}

THE study of astrology fascinated mankind for some two thousand years. The fundamental idea was the association of a god with each planet and the transfer of the god's character and mythology to the planet. As a result the planet itself was believed to exercise a direct influence on mankind. A crude form of astrology grew up in Mesopotamia in prehistoric times. But Martin P. Nilsson (Medd. Lunds Astron. Observ., ii, No. $111 ; 1943$ ) suggests that the great system of astrology properly so called was a product of the Hellenistic age. Though based on the false premise already mentioned, the study of the heavens was scientific, and was the result of the labours of a number of scientific observers in the Hellenistic world.

\section{Announcements}

The Gold Medal for 1947 of the Royal Astronomical Society has been awarded to Prof. M. G. J. Minnaert. of Utrecht, for his outstanding contribution to solar physics in general and solar spectrophotometry in particular.

THE annual general meeting of the Royal Meteorological Society will be held on January 22 at 5 p.m., when Mr. G. Manley will deliver his presidential address on "The Gengrapher's Contribution to Meteorology". The Symons Medal will be presented to Prof. David Brunt, in recognition of his distinguished services to meteorological science.

Prof. P. C. Sarbadhikary, professor of botany, University of Colombo (Ceylon), has been appointed Sir Rash Behari Ghosh professor of botany in the University of Calcutta in succession to Prof. S. P. Agharkar, who retired in May.

Mr. Ronatid Ede has been appointed agricultural attaché to the British Legation in Copenhagen. Mr. Ede, who is forty-one years of age, has been secretary of the University School of Agriculture at Cambridge since 1929. He was secretary of the Luxmoore Committee on Post-war Agricultural Education which reported in 1943.

Mr. W. J. Drummond, deputy chairman of the North-Western Divisional Coal Board, has been appointed honorary secretary of the British National Committee of the World Power Conference, in succession to the late Mr. C. Rodgers.

Colonel L. W. HaRrison has retired from the staff of the Ministry of Health, to which he has been adviser on venereal diseases since 1919. Colonel Harrison has been associated with the control of venereal diseases in England and Wales for nearly half a century. In recognition of his work the American Social Hygiene Association awarded him the William Freeman Snow Medal for 1946. He is the author of a number of books and papers on venereal disease.

The following have been elected officers for 1947 of the New York Academy of Sciences: President, Dr. Harden F. Taylor; Vice-Presidents, Dr. Robert B. Sosman, Dr. S. Stansfeld Sargent, Dr. Ross F. Nigrelli, Walter Dyk, Bernhard Haurwitz ; Recording Secretary, Dr. George B. Pegram ; Corresponding Secretary, Prof. Athelstan F. Spilhaus; Treasurer, Marvin D. Thorn; Librarian, Prof. Victor K. La Mer ; Editor, Dr. Roy Waldo Miner ; Members of Council (1947-49), William Brown Bell, Harry C. Charipper, Dr. Caryl P. Haskins; Finance Com. mittee, Addison Webb (chairman), William Ottis Sweet, Dr. Charles N. Frey. 